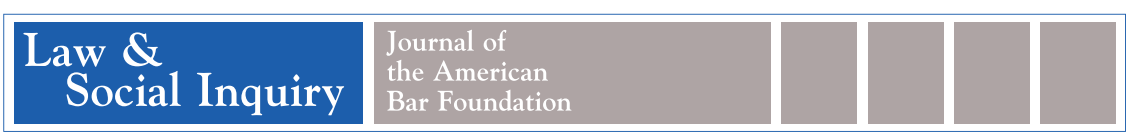

Law Eु Social Inquiry

Volume $\bullet \bullet$, Issue $\bullet \bullet, \bullet \bullet-\bullet \bullet, \bullet \bullet 2016$

\title{
Activist Lawyers in Post-Tiananmen China
}

Rachel E. Stern

Pils, Eva. 2014. China's Human Rights Lawyers: Advocacy and Resistance. New York: Routledge Press. Pp. xiv +297. \$155.00 cloth.

What do the activities of twenty-first-century Chinese lawyers tell us about the origins and prospects of legal activism under authoritarianism? This essay fits China's Human Rights Lawyers (2014) into an emerging literature on authoritarian legality. The book offers an insider view of a circle of lawyers interested in using China's newly accessible courts as a platform for social activism. It highlights the difficulty of rights lawyers' day-to-day work against the backdrop of the Chinese state's long-term experiment in how to harness the power of law without ceding political control.

In the decades since the 1989 Tiananmen Square Massacre, open political opposition in China has nearly dwindled away. Critics who might have become opposition politicians or underground revolutionaries in other countries, or even during other moments of Chinese history, have avoided founding organizations. ${ }^{1}$ On a smaller scale, too, vanishingly few individuals call themselves dissidents or publicly denounce the government. Nearly all of today's political criticism is framed as a loyal suggestion to improve Chinese Communist Party (CCP) leadership and, with so much political activity tacitly out of bounds, a good number of China's reformers have turned to law in recent years to flag injustice.

The rise of legal activism as a form of political participation in postTiananmen China is a familiar story, thanks to Western journalists' coverage of people such as Gao Zhisheng, Chen Guangcheng, and Pu Zhiqiang. These are civil rights lawyers who saw litigation as a route to social change, attracted national media attention, and fluently discussed both statutes and ideals. All three were also arrested, as part of a push to suppress lawyers deemed overly outspoken. To give context to the fate of $\mathrm{Gao}$, $\mathrm{Chen}, \mathrm{Pu}$, and others like them, an academic literature on China's political lawyers has sprouted alongside reports about their activities. ${ }^{2}$ Eva Pils's China's Human Rights Lawyers: Advocacy and Resistance is the latest addition to this collection. The book offers an in-depth look at the most politically liberal segment of the bar, China's roughly 200 human rights lawyers. What stands out is the depth of Pils's involvement with this group. Three years of interviews allow an insider view of the circle of lawyers that contains some of the CCP's

Rachel E. Stern is an Assistant Professor, in the Jurisprudence and Social Policy Program, Berkeley Law, She may be contacted at rstern@law.berkeley.edu. Many thanks to three anonymous reviewers from Law $\mathcal{E}$ Social Inquiry and to Eva Pils for comments that significantly improved this essay.

1. On the lack of membership organizations after 1989, see Potter $(2011,130)$.

2. For a cross-section of this literature, see Pils (2006-2007), Fu and Cullen (2008, 2011), Mosher and Poon (2009), Michelson and Liu (2010), Liu and Halliday (2011), Benney (2013), Givens (20132014), and $\mathrm{Fu}(2014)$. 


\section{LAW \& SOCIAL INQUIRY}

fiercest critics, ${ }^{3}$ and Pils writes that the book "seeks to capture and interpret [human rights lawyers'] experience and views" (5).

Pils's commitment to giving voice to Chinese human rights lawyers, and her sustained interactions with many of them, makes her book a valuable sketch of this milieu's aspirations and anxieties. It is a distant world from that of the average Chinese lawyer and, naturally, the decision to focus on a particularly politicized, Beijing-based subculture affects what Pils sees. This is clear from the start, as Pils describes her interlocutors' concerns about state monitoring. Most Chinese lawyers rarely think about surveillance, but Pils's informants habitually point out plainclothes policemen and turn off their cell phones to prevent tracking. One lawyer carries three phones: one to talk to his wife, another to "talk about [politically sensitive] issues" (shuo shi de dianhua), and a public one, which is usually turned off (192). Pils herself routinely interviews lawyers under house arrest and talks about making friends with the families of lawyers who have been detained.

This essay approaches China's Human Rights Lawyers from a law and society perspective, with an eye toward how the book fits into a standing tradition of research on activist lawyers, ${ }^{4}$ and the emerging field of authoritarian legality. This requires some extrapolation, as Pils was not writing with either audience in mind. Rather, her citations draw on journalism, political philosophy, and research on Chinese law to flesh out the historical and cultural context surrounding the interviews at the book's core. Looking slightly beyond what is on the page, then, what do the activities of twenty-first-century Chinese lawyers tell us about the origins and prospects of legal activism under authoritarianism?

One way to place China's Human Rights Lawyers is as part of a stream of research that treats authoritarian law as more complicated and consequential than earlier generations acknowledged. The popular image of authoritarian law dates back to legal sociologists Phillipe Nonet and Philip Selznick's description of "repressive law" in the late 1970s. For them, repressive law is subordinate to the needs of political authorities. This means that legal institutions are susceptible to state meddling, and "the interests of the governed" get "short shrift" $(2001,29)$. Nonet and Selznick penned this archetype during the Cold War, likely with the former USSR in mind (Hendley 2015, 535). Little was yet written about authoritarian law, and the idea that law can serve as a tool of state administration remains insightful. But as research on authoritarian law has swelled since the turn of the twenty-first century, ${ }^{5}$ one payoff has been a more nuanced understanding of how it works. Self-interested leaders often want well-functioning courts for a range of

3. Pils reports the book is based on conversations conducted with ninety-seven individuals, recruited through snowball sampling, and especially on interactions with a core group of one to two dozen key informants. She also spent significant time in informal conversations with human rights lawyers and was present at a good number of gatherings and events.

4. A variety of terms are used to describe activist lawyers in this literature, including cause lawyers (Sarat and Scheingold 2001, 2006; Marshall and Hale 2014), lawyers for social justice (Munger, Cummings, and Trubek 2013-2014), rebellious lawyers (Lopez 1992), and public interest lawyers (Yap and Lau 2010). A closely related strand of research looks more broadly at the political activities of lawyers, legal academics, judges, and prosecutors together as part of "the legal complex" (Halliday, Karpik, and Feeley 2007, 2011). Rather than delve into the differences between these strands of research, I discuss them together.

5. See Moustafa (2014) for an overview. 
reasons, from encouraging economic growth to fortifying the regime's popularity (Moustafa and Ginsburg 2008, 4-11). Insofar as courts provide fair, efficient, dispute resolution, at least in run-of-the-mill cases, ordinary people benefit. Erecting a legal framework can also open up possibilities for political activity. Even in politicized cases, when judges dare not rule against the government, legal action can call attention to issues and serve as a tool of political theater (Moustafa 2009, 40).

Seen through this lens, China is a massive, revolutionary experiment in whether an authoritarian state can harness the power of law without ceding political control. As Kathryn Hendley (2015) has argued in these pages, authoritarian law can combine political intrusion in high-profile cases with substantial independence when courts tackle more mundane fare. One way to understand China is as a "dualistic" or "bifurcated" legal system, where the rules depend on the political clout of the players and "law matters sometimes, but not always" (Hendley 2015, 547). ${ }^{6}$ This places China alongside Russia and Singapore as examples of legal systems that combine fair, efficient dispute resolution with ad hoc political meddling. ${ }^{7}$ Unlike governments that subscribe to only the shallowest and most selfserving view of law, these countries are committed to predictable legal procedures and acclimated to legal argument, at least most of the time. ${ }^{8}$ They treat fair, efficient dispute resolution as a public good, and aim to provide it without allowing courts to serve as an arena for political criticism.

In China, this balancing act is reflected in recent rounds of legal reforms designed to improve how well courts function without granting them independence from the Party. It is not yet clear whether this attempt to split judicial independence from judicial performance will succeed. ${ }^{9}$ The size of China has always made central control hard, and not everyone accepts legal construction as a state-run project. China's Human Rights Lawyers, and other similar work, trains our attention on a group of lawyers who see law as a coproduction between state and society. They believe that citizens are not passive receptors of rights and responsibilities bestowed by officialdom, but entitled to transform the law by using it. Against the backdrop of a strong and repressive state, Pils opens a window onto the activities of a minority committed to the idea that law can be produced by the legally subordinate. ${ }^{10}$

6. "Dualistic" is Hendley's word for the Russian legal system (Hendley 2009), while I have used "bifurcated" to describe Russia, China, and Singapore (Stern 2013, 229-30). For a similar argument in the mainstream press, see Lubman (2015).

7. It is up for debate exactly how judicial autonomy varies with the type of case. A number of scholars suggest bifurcated legal systems scrupulously follow laws related to commerce and the economy, while cases related to civil and political rights invite political interference (Silverstein 2003; Rajah 2011; Wang 2015).

8. For more on the distinction between authoritarian states that take formal legality seriously and those that do not, see Cheesman and San (2013-2014, 704). North Korea and Mynamar are good examples of countries with little regard for formal legality.

9. The distinction between judicial performance and judicial independence is borrowed from Michelson and $\mathrm{Li}$ (2014). As they point out, many observers conflate the two ideas because political interference is often tied to popular perceptions that law serves only those with political connections.

10. For another example of how law can be produced by those who are legally subordinate, see Laura Edwards's bottom-up legal history of the Civil War and Reconstruction, discussing how claims made by African Americans and women offered a "substantive critique of narrow, legalistic conceptions of equity" (2015, 142). 


\section{ACTIVIST LAWYERS IN CONTEXT}

Given China's tight (and tightening) controls over social activism, the sheer existence of a committed minority of activist lawyers seems unlikely, but Pils's scene setting makes once-strange specimens explicable, as she identifies the forerunners of today's legal activism. In so doing, she rightly points readers in two directions: toward international influence, but also toward strands of Chinese history.

International influence is easy to see because Chinese lawyers closely, if superficially, resemble their counterparts abroad. ${ }^{11}$ The average lawyer's dreams and worries are similar, from passing the bar, to drumming up clients, to making partner. When it comes to legal process and vocabulary, too, China's legal system is generally intelligible to lawyers trained elsewhere (146). If anything, the human rights lawyers in Pils's orbit are even more recognizable. This is a community committed to law that checks state power and makes real the values expressed in the Universal Declaration of Human Rights, familiar aspirations that make international influence seem self-evident. In part, this inference is correct. Pils acknowledges the abiding appeal of global conceptions of human rights, as well as the influence of such chroniclers of twentieth-century authoritarianism as Hannah Arendt, Adam Michnik, and Vaclav Havel. It is less clear how human rights lawyers encountered these thinkers or how many of Pils's interlocutors read their books. Did study abroad play a role, or Chinese translations of key works? It also would have been interesting to hear Pils's perspective on the extent to which Christianity inspires human rights lawyers - a theme of an earlier article Pils wrote about lawyer Gao Zhisheng ${ }^{12}$-and whether foreign funding is an important pathway of influence. ${ }^{13}$

However, Pils quickly moves past international diffusion to discuss how activist lawyers fit into the sweep of Chinese history. She starts in imperial China, with the tension between state distrust of troublemakers and two countertraditions: the right to petition government and officials' duty to confront unjust rulers. The latter reflects the Confucian ideal of remonstrance, and Chinese history is "replete with loyal officials pointing out ... injustice and (willingly) suffering the consequences" (27) ${ }^{14}$ Remonstrators were neither "whistle-blowers" nor "activists seeking to overthrow the regime," but patriots modeling rectitude (Andrew and LaFleur 2014, 7). When remonstrators accept punishment without resentment, their actions

11. For a discussion of the ways in which Chinese lawyers come out of a different professional tradition, and are not "cut from the same cloth as their American brethren," see Alford (2007) and Alford and Winston (2011).

12. See Pils (2006-2007). Liu and Halliday also note "a significant proportion of activist lawyers in Beijing are Christian" (2011, 853). As one lawyer explained, "I believe there is an inner connection between the work we are doing and the belief that we have. The Christian values are confirming what we are doing: freedom, equity, justice" (quoted in Liu and Halliday 2011, 853).

13. Pils does not discuss foreign funding, which may well be because her interviewees were not accepting much of it. However, children's rights, women's rights, environmental rights, and labor rights are all areas in which well-established Chinese public interest law organizations are also longstanding recipients of foreign financial support. International funding is often key to organizational survival, though some Chinese lawyers also worry that it leaves them vulnerable to accusations of undue foreign influence. For more on foreign funding, see Fu and Cullen (2011), Stern (2013), and Wei (2015).

14. In fact, some see the 1989 Chinese democracy activists as remonstrators rather than dissidents (Nathan 1986). 
strengthen state authority rather than undermining it (Nathan 1986, 25-26). The second countertradition is the custom of letting commoners appeal to the authorities to fix injustices. ${ }^{15}$ Petitioning is premised on paternalism, and applicants approach the state in a spirit of "intimacy, trust, supplication, and submissiveness" (30). Today, Pils points to remonstrance and petitioning as Chinese cultural resources that help activist lawyers squeeze into notions of appropriate political behavior. Even activist lawyers who subscribe to liberal ideas about law, politics, and rights can cast themselves as part of an indigenous David versus Goliath tradition that celebrates the brave few willing to identify injustice, confront state power, and bear the consequences.

China's early twentieth-century advocates for political liberalism are an additional source of inspiration. Human rights lawyers express nostalgia for Republican China (1912-1949) as China's "most hopeful era" (37). They do not miss the warlords or exploitative landlords the period calls to mind, but the intellectual currents and spirit of possibility. The era of emperors was clearly over, and there was vigorous debate about the political form best suited to rejuvenate and unify China. It was also "a high-tide of internationalism," to borrow historian William Kirby's phrase, and many thinkers advocated the adoption of imported ideas, including democracy, civil rights, and constitutionalism (1997, 457). Pils's point, though, is less about the historical record than the importance of historical memory. When they reference the first half of the twentieth century, human rights lawyers in their thirties and forties are regretting a wasted opportunity. At the same time, though, there is solace to be drawn from the fellowship of long-gone kindred spirits, and reassurance in the memory of others who believed rights and law were key to China's future.

If we are on the hunt for indigenous antecedents to today's legal activism, remonstrance, petitioning, and twentieth-century political liberalism are a good start. These legacies give activist lawyers a degree of cultural resonance, and make it harder to dismiss lobbying and litigation as peculiarly democratic foreign imports. One important twentieth-century tradition is missing from Pils's list, however, and this is socialism. Many activist lawyers advocate for the "weak and disadvantaged groups" (ruoshi qunti) left behind by China's economic boom, and an impulse to aid today's peasants and proletariat is decidedly socialist. By bringing law to the masses, lawyers can also help the CCP live up to its historical commitment to egalitarianism. Elsewhere in the world, too, there is evidence that socialist ideals inspire idealistic lawyers. In Cuba, for example, lawyers committed to the revolution voluntarily formed law collectives to give the poor access to justice (Michalowski 1998). In contemporary Vietnam, too, some activist lawyers forego civil rights language in favor of "socialist narratives" of flexible, distributive justice (Gillespie 2013, 700).

Most likely, Pils only briefly mentions socialism because human rights lawyers themselves rarely discussed it. Here, it is important to remember that human rights lawyers are a particular subculture, and socialism might have arisen as a more prominent theme if Pils had interviewed a wider swath of lawyers. In the interviews for

15. On petitioning in the Qing dynasty, also see Ocko (1988). For more on contemporary petitioning, see Minzner (2006). 
my book on environmental litigation, in contrast, I found that some environmental lawyers are sincerely inspired by China's socialist legacy and others strategically deploy socialist rhetoric to give their work a gloss of historical continuity (Stern 2013). Code switching is common, as lawyers try to win support from multiple audiences, and I often found it hard to distinguish a belief state-led socialism from small-s socialism - the belief that lawyers can lessen inequality through law. Nether strand of socialism, though, appears in China's Human Rights Lawyers. Pils portrays this group of lawyers as oriented toward political rights, rather than economic rights, and inspired by strands of China's past that predate the CCP's socialist project.

\section{PROSPECTS FOR POLITICAL LAWYERS UNDER AUTHORITARIANISM}

China's politically inclined lawyers work under extraordinarily difficult conditions and their troubles form the backbone of Pils's book. A chapter on bureaucratic control, for example, rightly calls attention to the coercive pressure of annual government reviews of lawyers and law firms. ${ }^{16}$ Outspoken lawyers can be disbarred on trumped-up charges of incompetence, and parallel assessments of law firms press lawyers to rein in colleagues. As one lawyer told Pils, "my law firm head said to me, 'if you weren't in our firm, the justice bureau wouldn't even know me!” (160). Threats of disbarment also helped disband a well-known Beijing-based public interest law firm, an incident Pils recounts at some length (170-74). ${ }^{17}$ One firm founder describes a strategy of "forced demolition," in which the authorities asked each lawyer: "do you want to be a lawyer or not? If yes, then leave X law firm ... right now! But if you want to stay in X Law Firm, you will find you are no longer able to handle any cases in the future" (183). All but one partner resigned after two such "demolition rounds" in 2009. This touched off a scramble to meet the Justice Bureau's three-partner minimum requirement, which culminated in another crisis: the landlord's refusal to renew the lease because of political pressure. ${ }^{18}$

Bureaucratic control also quickly shades into threats, violence, surveillance, and detention. Pils details human rights lawyers' curiously intimate relationship with the internal police (guobao). Officers stay in close touch with high-priority "targets" though phone calls, text messages, and in-person chats, sometimes also intimidating lawyers' family and friends. Lawyers internally calculate how much pressure loved ones can bear, in addition to assessing their own tolerance for risk. ${ }^{19}$ Ambitious guobao officers are the most zealous, Pils observes, and torture in police custody is common. Stretches of China's Human Rights Lawyers recount lawyers' harrowing experiences. "They pushed me down by the neck," one lawyer remembers,

16. For more on the pressure exerted by yearly appraisals, see Committee to Support Chinese Lawyers and the Leitner Center $(2015,49-57)$.

17. Pils anonymizes the name of the law firm, referring to it only as X Law Firm.

18. Once the remaining lawyers found space in another district, the Justice Bureau refused to register the new office.

19. Pressuring family and friends is a common tactic that Deng and O'Brien (2013) term "relational repression." 
and "did not allow me to speak ... [they told me] things like 'Be a bit clever!' and 'Show some quality!' - what they mean by quality ... just means being compliant" (213). Outside detention centers, too, violence is sometimes used to scare lawyers into dropping cases. In one such attempt, a lawyer representing Falun Gong practitioners lost his computer, mobile phone, and shoes in a middle-of-the-night raid on his hotel. After wearing hotel slippers to court the next day, he published an online account of his experiences entitled "Account of a Curious Robbery-Deeply Thanking My Robbers for Taking No Valuables" (110). Given widespread state-sponsored intimidation and surveillance, it is not surprising most human rights lawyers piece together a career "ridden with failures" (1).

The bleakness of Pils's portrait raises questions about motivation. Under such unpromising conditions, what compels even a handful of lawyers to action? Oddly, given Pils's commitment to an "experience near" approach aimed at capturing how people "see, feel, think, and imagine," as the anthropologist Clifford Geertz described it, little space is spent on motives $(1974,28)$. Instead, Pils lists the many grievances that transform lawyers into activists:

a wide spectrum of wrongs forms the basis of rights lawyering in China ... torture, wrongful convictions and extrajudicial incarceration; forced evictions, housing demolitions and land expropriations; food and medicine poisoning; forced abortions; discrimination; internet censorship; labour rights violations; 'law enforcement' abuses; psychiatric and other medical abuses; official corruption and official dereliction of duty; and pollution of the air, soil and groundwater. (66)

The suggestion is that exposure to injustice spurs action, a common path to recruitment elsewhere too. As others have chronicled, many lawyers stumble into activism through individual cases (Shamir and Chinski 1988; Marshall and Hale 2014), and only later dedicate themselves to ideals such as human rights or rule of law. By the time Pils reaches them, many Chinese human rights lawyers have embraced a rights-centered approach to law more attuned to moral purpose than results. They share an imperative to act, even if the government responds with repression, or fails to respond at all.

Although moral protesters exist worldwide, what is unusual about China is how law has emerged as such a prominent vocabulary and venue for political criticism despite a decided lack of judicial independence. ${ }^{20}$ Pils takes a historical approach to understanding this paradox, tracing today's activism to the "climate of

20. Although measuring judicial independence is a challenge, and definitions differ, analysts agree China has relatively little of it. On the quantitative side of the ledger, Linzer and Staton suggest China's low stock of judicial independence hardly budged between 1948 and 2012 (2015, 246). Likewise, Munger, Cummings, and Trubek's qualitative analysis points to judicial autonomy as one of two factors that shape possibilities for social justice lawyers in Asia. The other factor is political openness, or opportunities to express dissent outside legal institutions. This framework places China alongside Mynamar and Vietnam as one the toughest spots for legal activism in Asia, thanks to low autonomy and lack of political openness (Munger, Cummings, and Trubek 2013-2014). In this essay, I treat judicial independence and judicial autonomy as synonyms, defined as the degree to which political elites stand above the law or are obliged to follow it. 
reform optimism" that accompanied official efforts to professionalize the judiciary, learn about Western law, and popularize legal knowledge in the 1980s and 1990s (49). In this retelling, legal activism is an outgrowth of the state's own reform agenda. This is true, though China's Human Rights Lawyers stops short of bringing this story of institutional evolution up to the present by examining a critical set of policies: the rules governing who can bring a case to court and how much it will cost. ${ }^{21}$

Access to justice is a recurrent theme of Chinese legal reforms, perhaps due to the communist idea that power belongs to the people or perhaps because dispute resolution is seen as a pillar of regime legitimacy. The past decade, in particular, has seen many examples of policies and regulations aimed at democratizing court access. The State Council slashed court fees in civil cases in 2007, for instance, and the legal aid budget rose 87 -fold between 2000 and $2014 .^{22}$ Most recently, a 2015 change to docketing procedures attempted to address complaints that courts screen out cases that might spark protest, or otherwise prove difficult to handle. ${ }^{23}$ Under the new case filing registration system (li'an dengji zhi), the legal merit of a complaint is assessed after the case is filed rather than at the court door. By removing discretion from the judges who process the initial paperwork, the goal is to reduce local power holders' influence over the court docket. $^{24}$

This is all to say that Chinese courts today are reasonably open to the average citizen, even though no one would claim that going to court is easy and plenty of people prefer to resolve problems in other ways. Legal representation is common, too. As legal scholar Hualing Fu writes, "the direct obstruction of legal representation, even for the worse enemy of the CCP, is no longer feasible" $(2014,278)$. The promise of a trial, especially with a lawyer present, makes it possible to repurpose courts as a platform for a cause. Perhaps it is too obvious for Pils to mention, but for all the manifold difficulties of pursuing human rights in China, the rules governing access are what make the work possible. The court doors have to be cracked open, in short, before legal activism under authoritarianism becomes imaginable.

21. This maps onto the concept of "legal opportunity" developed by sociolegal scholars (Hilson 2002; Andersen 2006; Vanhala 2010, 2012). Though there is no standard definition of legal opportunity, and some attempts are so broad as to be meaningless, Vanhala identifies a "general consensus" that the "procedural rules constraining or enhancing access to justice" are vital $(2012,527)$. Concretely, this elevates standing and costs to central concerns.

22. The budget rose from 19 million RMB in 2000 (China Law Yearbook) to 1.7 billion in 2015 (China Legal Aid Online). This far outpaces inflation, which OCED data estimate at 39 percent over the same fifteen-year period. On the reduction of court fees, see Stern $(2013,54)$.

23. On how courts screen cases, see Stern (2013, 47-48), and Lei and Zhou (2015, 582-83).

24. The impact of the new docketing procedures is not yet clear. Xinhua, the state-run news agency, reports civil lawsuits jumped 29 percent and administrative lawsuits 221 percent during the first month of the new policy (2015). In addition to general agreement that the new procedures aim to reduce local influence, several other interesting rationales have also surfaced. According to the Supreme People's Court, the intent is to implement the spirit of the Fourth Plenum and protect citizens' right to sue (baozhang suquan) (SPC 2015). Other commentators tout court access as a route to renewed judicial prestige (Xu 2015) and a solution to the problem that belief in the petition system eclipses trust in the courts ( xinfang bu xin fa). 


\section{WHY STUDY THE FRINGE?}

Sooner or later, students of authoritarian legal activism encounter skeptics dubious that the activities of a tiny minority matter. At least some readers of China's Human Rights Lawyers will surely wonder whether several hundred human rights lawyers can have an impact in a country of 1.3 billion. Does focusing on the fringe risk missing a bigger story about the evolution of the mainstream legal profession? Perhaps most troubling, are US and European observers unusually interested in activist lawyers because we like to celebrate champions against authoritarianism? In her introduction, Pils acknowledges a debate over whether the "plight of a handful" tells us much about the majority and argues that human rights lawyers' experiences expose broader currents in Chinese society (6). However, there are three additional stronger justifications implicit in the project. These rationales are worth bringing to the surface because the debate over topic-worthiness is important. Collectively, the evolution of a field depends on which topics are deemed worthy of attention and, individually, scholars deliberate which projects to tackle in an alltoo-finite career.

The first argument is that activist lawyers act as a vanguard. At least in China, proponents of this argument tend to flash forward to future possibilities because present evidence of influence is scant. Although one survey shows that Chinese lawyers attach far greater importance to political rights than does the average citizen, most aspire to better protect themselves from angry clients, law firm demands, and state agents, rather than systemic political reform (Michelson and Liu 2011, 328). Nearly all studies of the Chinese legal profession agree, and paint a portrait of the average Chinese lawyer as hustling to make money and get ahead. As sociologist Ethan Michelson's now-classic dissertation concludes, Chinese lawyers are "a politically conservative force" who "stymie political change" rather than advance it (2003, 401). Unlike other countries in which lawyers' fading financial prospects have contributed to unrest, such as Tunisia (Gobe and and Salaymeh 2016), the bulk of the Chinese bar has enjoyed upward economic mobility over the past fifteen years. Still, there is always a possibility that today's beleaguered minority could become tomorrow's revolutionaries. In his award-winning book, Age of Ambition, journalist Evan Osnos makes this case. As he writes, "ignoring the impact of a small group of impassioned people struck me as a misreading of Chinese history, in which small groups had often exerted large forces" $(2014,228)$.

A second argument is that the gradual accretion of small changes can produce larger transformation. Weapons of the Weak, James Scott's treatise on peasant resistance, contains an influential iteration of this line of reasoning. Scott argues that "multiple acts of peasant insubordination and evasion" can amass into "political and economic barrier reefs" upon which "the ship of state runs aground" (1987, xvii). Following Scott, a number of recent writings on authoritarian legal activism make a similar case that grassroots activism can rewrite the rules of political engagement even absent regime change. In their research on the criminal defense bar, for example, Liu and Halliday see a fight for "basic legal freedoms" unfolding "incrementally, locally and case-by-case ... across the vast landscape of China's heterogeneous regions" $(2011,862)$. My work on environmental litigation in China, 
too, speaks to a quiet story of small changes that show how law is slowly remaking China (2013). And Lynette Chua's history of Singapore's LGBT movement documents the creeping emergence of political demands and public displays unthinkable twenty years earlier (2014). In echoing Scott, this new generation of law and society research captures a shared sense that legal activism is a noteworthy social force even in the absence of political liberalization. Pils's chapter on courtroom advocacy likewise winds up in Scott-like territory, albeit less explicitly. Vigorous legal representation "unsettles the entrenched judicial process, exposes its inequities, and sometimes ... win[s] better results for clients" (140). ${ }^{25}$ There are a few other side effects, too. Advocacy can forge collective memories, strengthen advocates' selfworth, and prompt enough publicity to attract allies. ${ }^{26}$

The third approach is to reject the idea that China's human rights lawyers are only worthy of attention if they achieve results. Even if political critics perpetually fail, their struggles tell us a great deal about the architecture of state power. One way to read China's Human Rights Lawyers is as a portrait of the state as viewed from below, from the perspective of gadflies who knowingly provoke the bureaucracy. ${ }^{27}$ The book conjures an atmospheric sense of shifting political terrain, and what it is like to navigate an environment in which "divining how far any individual could go" is "akin to carving a line in the sand at low tide in the dark" (Osnos 2014, 230). Much of this material echoes earlier work about how uncertainty and self-censorship sustain CCP control. ${ }^{28}$ As one of Pils's interviewees explains, "what an authoritarian society needs to achieve most is that you are so afraid that they don't even need to tell you what not to do-you just won't do it" (220). But Pils argues that the promise of safety through self-censorship is illusory. A quote from Teng Biao, one of China's best-known human rights lawyers, makes the point eloquently:

If you cause the government a little less trouble, your level of safety will rise ... But the question is, to what level will you retreat? You retreat one step and feel that's still not enough, so you retreat two steps ... and you will have to retreat further, all the way back to when you have reached the bottom line, and will have to pretend to be deaf and mute. (222)

25. Pereira makes a similar argument about how defense lawyers in Brazil's military courts stretched the boundaries of permissible activity and speech within national security law, and served to lay the foundations for a proto-civil society that demanded fuller respect for human rights $(2005,156)$.

26. Some readers will feel this list does not amount to much. After all, what good is curbing state power by insisting on proper procedures or arguing for reduced punishment when the same people remain in charge? Others, including me, will be more amenable to research that grapples with long-term social processes and, as a result, sometimes records stretches of incremental advances. In this way of thinking, waiting for clear-cut changes such as policy reversals and regime change risks missing the action between timelineworthy events.

27. For more on a "state reflected in society" approach, see Stern and O'Brien (2012).

28. For more on self-censorship and uncertainty, see Link (2002) and Stern and Hassid (2012). Pils takes a strong stand that uncertainty is a conscious state strategy. As she writes, "precisely intelligible warnings or commands would be counter to the purposes of the Party-State. What is useful to it, rather, is the creation of a psychological state of uncertainty" (220). 
Pils's portrait of Chinese state power is at its sharpest when she travels beyond the by-now familiar topography of self-censorship and uncertainty to traverse psychological terrain. For example, take her nuanced perspective on disbarment. On one hand, this "highly invasive measure of retaliation for advocacy" can "deeply damage ... lawyers' feelings of self worth" (176). As one lawyer put it, "it is a problem of identity (shenfen $)^{29}$... you are simply no longer a lawyer if you have lost the license" (176). At the same time, however, disbarment can also feel like an escape from bureaucratic control and a form of psychological liberation (182). Human rights lawyers also react differently to statements of repentance (huiguoshu) or promises about future behavior (baozhengshu) extracted by torture. Some dismiss these admissions easily, while others feel acute moral humiliation. "There really are people who will look down on you for having written such a thing," one lawyer told Pils. "In Communist education, these types of letters were ... taken extremely seriously. If someone betrayed their political views after having been detained, it was a really serious matter" (216).

Pils's deep empathy for her subjects also triggers frustration with the "grids, rankings, and taxonomies" that distinguish different types of activist lawyers (275). The most influential of these classification schemes sorts Chinese activist lawyers into three categories - moderate, critical, and radical—depending on the political sensitivity of the lawyer's caseload, the political objectives at play, and whether out-of-court networks are routinely rallied to the cause (Fu and Cullen 2008). For Pils, the intellectual reward of mapping these fractures does not justify the marginalization of the human rights lawyers deemed "radical." Much like those she profiles, Pils insists that fighting to fulfill the constitutional promise of equality before the law is not extreme. What counts as "politically sensitive" is determined by "the average level of who is currently in prison," as the lawyer Teng Biao puts it, and the radical label only spreads the hegemonic idea that some activities are overly provocative (278). Plus, moderation is no guarantee of safety. "They [the authorities] always need someone to be at the top of the list of enemies of the State," one interviewee tells Pils. "It is a different person at different times, but there always has to be somebody" (278).

This is a good point about how writers should be careful about adopting labels that reflect the authorities' worldview. Although Pils offers no alternative, her rejection of "radical" reminds us how easy it is to cast human rights lawyers as troublemakers (in the Chinese government's vocabulary) or democratic heroes (as often discussed abroad). Yet taxonomies are an essential step toward mapping a diverse world and understanding the tactical and political disagreements that divide adjacent social circles. Many Chinese lawyers are also keen to discuss their choices and position themselves in relation to others. ${ }^{30} \mathrm{~A}$ commitment to an experience-near approach, then, seems to demand discussion of how rights lawyers view differences among themselves. In addition, categorization makes it easier to think about

29. This quote diverges slightly from Pils, who translates shenfen as "status/identity."

30. The observation that activist lawyers are keen to discuss the fissures between them is drawn from my own experience. For an example of how an insider characterizes the different groups within the broader "rights defense" movement, see Wei (2015). 
radicalization (or retreat) over time. Fu (2014), for example, links the emergence of a group of so-called die hard criminal defense lawyers with a broader "subtle, but visible shift ... toward a more radical style" (288). Is he right? It is hard to weigh in without a sense of the rhetoric and activities dividing the lawyers who are considered boundary-pushers from the mainstream.

\section{WHAT NEXT?}

In most conversations about Chinese activist lawyers, the "what next" question swirls continuously, rising to particular prominence after each crackdown on legal activism. Over the past decade, the authorities have consistently clipped the bar's radical flank by locking up the lawyers with the most extreme views and tactics. At times, too, individual sanctions have swelled into wider-spread campaigns. For example, news reports documented a surge in surveillance, harassment, and arrests ahead of the 2008 Olympics, in response to the 2011 Jasmine Revolution, during the run-up to the twenty-fifth anniversary of Tiananmen Square in 2014, and over the summer of 2015. ${ }^{31}$ This lengthening history of punctuated repression overlays a debate, both inside and outside China, about whether activist lawyers are gaining strength. In a 2014 speech at Purdue University, Teng Biao made the optimist's case that the arc of the moral universe bends toward justice:

The rights defense movement will get more people to approve of rule of law (fazhi), and use the protection of the law to protect citizen rights. Although many cases will not be successful, the influence of human rights lawyers will grow in the process of bringing them. ${ }^{32}$

Echoing Teng, the Brooking Institution's Cheng Li interprets the growing strength of China's legal profession as a good sign for "the rise of the rule of law" (2015). Some also see demographic trends as cause for hope. The ranks of political lawyers has expanded as the bar has grown, at least so far, and newly politicized lawyers often migrate to Beijing in search of a climate amenable to activism (Liu, Liang, and Michelson 2014, 179). ${ }^{33}$

However, the intensifying repression of President Xi Jinping's early years in power makes pessimism increasingly difficult to reject. Inside China, lawyer Wei Rujiu claims the ranks of rights defense lawyers are shrinking and borrows Sun Yatsen's famous metaphor to compare their disunity to "a sheet of loose sand" (2015). ${ }^{34}$ Outside China, too, many observers of China's legal development see "a

31. For two human rights reports that summarize developments over this period, see Human Rights Watch (2008) and the Committee to Support Chinese Lawyers and the Leitner Center (2015).

32. Reporters sometimes make a similar argument. In the wake of the 2015 crackdown on human rights lawyers, for example, Andrew Jacobs and Chris Buckley (2015) of The New York Times wrote that "the ranks of lawyers willing to take on politically sensitive cases has only grown in recent years. They are a sliver of China's 270,000 lawyers, but one with an outsize influence on public life."

33. I'm grateful an anonymous Law $\mathcal{E}$ Social Inquiry reviewer for making this point.

34. Sun Yatsen (1866-1925) is key figure in twentieth-century Chinese politics. He cofounded the Kuomintang Party (KMT) and played a key role in the 1912 fall of the Qing Dynasty. In a series of lectures in 1924, he famously compared China to a "sheet of loose sand," and called for national unity to reverse 
gradual, evolutionary path" toward activist lawyers becoming "a moderate, institutionalized political force" quietly disappearing (Minzner 2015, 141). ${ }^{35}$ At times, Pils seems to share this point of view. She writes, for example, that the pervasiveness of state control makes it hard to place credence in "liberalization narrative[s]" that cast lawyers as a "force for greater rights orientation" in the legal system (179). Some human rights lawyers are also clearly losing faith in the possibility of incremental reform, and bracing themselves for the possibility of violence ahead.

Overall, however, Pils avoids too much speculation about the future in favor of a tighter focus on the 2010-2013 period of her fieldwork. This could reflect a desire to stay close to the data, or the difficulty of settling on a master narrative when Chinese legal activism remains novel and outcomes unsettled. To draw an American analogy, China's lawyers are in a period akin to how civil rights lawyers experienced the 1940s; a time of ferment before the 1954 Brown v. Board of Education decision channeled legal energy toward some cases and legal theories and not others. ${ }^{36}$ Tactics and doctrine are hotly contested, as Chinese lawyers grapple for the best legal handholds. Unlike 1940s United States, though, China lacks a support structure of organizations like the Civil Rights Section of the Department of Justice or the legal department of the NAACP. ${ }^{37}$ Government wariness of civil society has atomized China's activist lawyers to a point where most discussion of strategic choices takes place through social networks, both online and offline, rather than in organizations. No wonder, then, that many researchers profile individuals, as Pils does, and leave their successors the task of splicing assorted snapshots into a portrait of twenty-first-century legal activism. So far, what seems to be emerging is a stretch of legal experimentation, as lawyers debate which grievances to represent and how to pursue them.

Even if a definitive account of the longue durée is yet to come, one theme that emerges from China's Human Rights Lawyers is the interplay between tactical innovation and efforts to clamp down on new approaches. Over time, the CCP has become touchier about some tactics, especially public demonstrations, media outreach, and disruptions to court procedure. The Xinhua editorial justifying the 2015 crackdown on human rights lawyers expresses these misgivings clearly: "they [the lawyers] are suspected of seeking profit by illegally organizing paid protests, and hyping controversies to sway court decisions. Their acts also included insulting judges and police at court [and] forcing trials to a halt" (Xinhua News Agency 2015). The unwritten rules of engagement can shift quickly, and some tactics Pils

national weakness. In his words: "Despite four hundred million people gathered in one China, we are, in fact, but a sheet of loose sand. We are the poorest and weakest state in the world, occupying the lowest position in international affairs; the rest of mankind is the carving knife and the serving dish, while we are the fish and meat ... If we do not earnestly promote nationalism and weld together our four hundred millions into a strong nation, we face a tragedy - the loss of our country and the destruction of our race" (quoted in Schell and Delury 2013, 131).

35. Columbia Law's Benjamin Libeman likewise sees "little evidence" that Chinese legal institutions are becoming "sites of resistance to authoritarian rule" $(2014,103)$.

36. Goluboff (2007) excavates a 1940s history of civil rights litigation inspired by working-class harms. She sees the 1940s as an era before "the canonization of a Brown-inspired race-based understanding of civil rights" when the law was "conceptually, doctrinally, and constitutionally up for grabs" $(270,5)$.

37. For more on the importance of a support structure, see Epp (1998). 
observed-especially the performance art that lawyers occasionally organized to attract media attention - may already be buried in a graveyard of off-limits strategies.

Limiting forms of permissible activism is also part of a larger CCP effort to cleave individualized legal aid from lawsuits that bridge into wider advocacy. ${ }^{38}$ After all, legal aid is atomized and unthreatening. It helps preserve stability, as Ministry of Justice Vice-Minister Zhou Dacheng said in a 2015 interview, by solving everyday problems so people can "live and work peacefully and happily" (anju leye) (Ministry of Justice 2015). One sign of official support for legal aid is how much the program has grown over the past fifteen years. Government-run legal aid agencies supplied legal representation for 1.3 million clients in 2014, five times the 249,654 served in 2000. ${ }^{39}$ Compared to those who provide direct legal services to the poor, though, lawyers with a political agenda are much more of a menace. These are the lawyers who position themselves "outside the system "(tizhiwai), and are as likely to ignore official warnings about case selection, legal arguments, or tactics as to heed them. ${ }^{40}$

But this fight over the appropriate role of legal aid would not erupt in many authoritarian states. The world's kleptocrats and despots rarely place fair, efficient dispute resolution on their political agenda, let alone legal services for the poor. In failed states and poverty-stricken countries, too, there is neither money nor political will to support legal aid. China is an unusual member of the authoritarian club. Today's CCP runs a government with long time horizons, a decent budget, and a claim to legitimacy that rests on governing well. Under these three conditions, trying to satisfy court users' expectations-while also occasionally letting law take a back seat to political needs-is a logical strategy. But can dualistic legal systems ever be long-lived and large scale? Ernst Fraenkel documented how justice in Nazi Germany differentiated between political cases and ordinary ones, but that legal system thankfully collapsed inside a decade ([1941] 2010). And for all of Singapore's success fusing political repression with exemplary commercial law, it remains a citystate with a population under 6 million. In comparison, China is pursuing bifurcated justice on an unusually long time frame and scale. My question is whether the state can keep control over who enters the courthouse after throwing the doors open.

Pils, however, evokes a different image at several points: human rights lawyers purposefully walking out of the courts to pursue advocacy in the streets and on the

38. For American readers, the distinction between direct legal services and social change litigation may feel familiar. The CCP's distrust of social change advocacy, and concurrent fondness for individual pro bono work, echoes arguments made in the 1980s by then-President Ronald Reagan and other critics of the Legal Services Corporation. The political leadership of 1980s America and twenty-first-century China are similarly wary of letting a minority turn the courts into a venue for social activism. Instead, social change should be rightfully steered by another political institution, either the legislature (in the view of 1980s US conservatives) or the Chinese Communist Party. In both countries, debates over the legitimate scope of litigation pit reformers against defenders of the status quo. For a discussion of the 1980s debate over the Legal Services Corporation, see Albiston and Nielsen (2014, 66-70).

39. Despite growth, the scale of legal aid remains modest compared to the 14.21 million cases heard by Chinese courts in 2013 (Xinhua News Agency 2014).

40. For more on the steady streams of warnings that lawyers receive, see Givens (2013-2014). For a useful discussion of the difference between operating inside and outside the system, see Pils (2014, 64-65). 
Internet. Both Pils and the lawyers she profiles see courts as state spaces subject to multiple lines of control, including turning away cases, dictating decisions, and locking up lawyers. Grassroots mobilization can be trickier to stamp out, and China's Human Rights Lawyers leaves another question lingering: What happens if the lawyers refuse to stay in the courthouse?

\section{REFERENCES}

Albiston, Catherine R., and Laura Beth Nielsen. 2014. Funding the Cause: How Public Interest Law Organizations Fund Their Activities and Why It Matters for Social Change. Law $\mathcal{E}$ Social Inquiry 39 (1): 62-95.

Alford, William P., ed. 2007. Raising the Bar: The Emerging Legal Profession in East Asia. Cambridge, MA: Harvard University Press.

Alford, William P., and Kenneth I. Winston. 2011. Introduction. In Prospects for the Professions in China, 1-22. New York: Routledge.

Andersen, Ellen Ann. 2006. Out of the Closets $\mathcal{E}$ Into the Courts: Legal Opportunity Structure and Gay Rights Litigation. Ann Arbor, MI: University of Michigan Press.

Andrew, Anita, and Rober Andre LaFleur. 2014. Remonstrance: The Moral Imperative of the Chinese Scholar-Official. Education About Asia 19 (2): 5-8.

Benney, Jonathan. 2013. Defending Rights in Contemporary China. New York: Routledge.

Cheesman, Nick, and Kyaw Min San. 2013-2014. Not Just Defending; Advocating for Law in Myanmar. Wisconsin International Law Journal 31 (3): 702-33.

Chua, Lynette J. 2014. Mobilizing Gay Singapore: Rights and Resistance in an Authoritarian State. Philadelphia, PA: Temple University Press.

Committee to Support Chinese Lawyers and the Leitner Center. 2015. Plights and Prospects: The Landscape for Cause Lawyers in China. Available at http://tinyurl.com/nfakohs (accessed July 25, 2016).

Deng, Yanhua, and Kevin J. O'Brien. 2013. Relational Repression in China: Using Social Ties to Demobilize Protesters. China Quarterly 215:533-52.

Epp, Charles R. 1998. The Rights Revolution: Lawyers, Activists, and Supreme Courts in Comparative Perspective. Chicago, IL: University of Chicago Press.

Fraenkel, Ernst. [1941] 2010. The Dual State: A Contribution to the Theory of Dictatorship. Clark N.J. Lawbook Exchange, Ltd. (Originally published by Oxford University Press in 1941.)

Fu, Hualing. 2014. Human Rights Lawyering in Chinese Courtrooms. Chinese Journal of Comparative Law 2 (2): 270-88.

Fu, Hualing, and Richard Cullen. 2008. Weiquan (Rights Protection) Lawyering in an Authoritarian State: Building a Culture of Public-Interest Lawyering. China Journal 59:111-27. . 2011. Climbing the Weiquan Ladder: A Radicalizing Process for Rights-Protection Lawyers. China Quarterly 205:40-59.

Geertz, Clifford. 1974. "From the Native's Point of View": On the Nature of Anthropological Understanding. Bulletin of the American Academy of Arts and Sciences 28 (1): 26-45.

Gillespie, John. 2013. The Jurifidication of Cause Advocacy in Socialist Asia: Vietnam as a Case Study. Wisconsin International Law Journal 31: 672-701.

Givens, John Wagner. 2013-2014. Sleeping with Dragons? Politically Embedded Lawyers Suing the Chinese State. Wisconsin International Law Journal 31 (3): 734-75.

Gobe, Eric, and Lena Salaymeh. 2016. Tunisia's 'Revolutionary' Lawyers: From Professional Autonomy to Political Mobilization: Tunisia's 'Revolutionary' Lawyers. Law EO Social Inquiry 41 (2): 311-45.

Goluboff, Risa. 2007. The Lost Promise of Civil Rights. Cambridge, MA: Harvard University Press. 
Halliday, Terence C., Lucien Karpik, and Malcolm Feeley, eds. 2007. Fighting for Political Freedom: Comparative Studies of the Legal Complex and Political Liberalism. Oñati International Series in Law and Society. Oxford/Portland, OR: Hart.

—. eds. 2012. Fates of Political Liberalism in the British Post-Colony: The Politics of the Legal Complex. Cambridge, NY: Cambridge University Press.

Hendley, Kathryn. 2009. "Telephone Law" and the "Rule of Law": The Russian Case. Hague Journal on the Rule of Law 1 (02): 241-62.

2015. Resisting Multiple Narratives of Law in Transition Countries: Russia and Beyond: Narratives of Law in Transition Countries. Law $\mathcal{E}$ Social Inquiry 40 (2): 531-52.

Hilson, Chris. 2002. New Social Movements: The Role of Legal Opportunity. Journal of European Public Policy 9 (2): 238-55.

Human Rights Watch. 2008. Walking on Thin Ice: Control, Intimidation and Harassment of Lawyers in China. New York: Human Rights Watch. http://tinyurl.com/glm29hs (accessed July 25, 2016).

Jacobs, Andrew, and Chris Buckley. 2015. China Targeting Rights Lawyers in a Crackdown. The New York Times, July 22. http://tinyurl.com/nvyxcbj (accessed July 25, 2016).

Kirby, William C. 1997. The Internationalization of China: Foreign Relations at Home and Abroad in the Republican Era. China Quarterly 150:433-58.

Lei, Ya-Wen, and Daniel Xiaodan Zhou. 2015. Contesting Legality in Authoritarian Contexts: Food Safety, Rule of Law and China's Networked Public Sphere. Law $\mathcal{B}$ Society Review 49 (3): 557-93.

Li, Cheng, David Daokui Li, and Malan Rietveld. 2015. The Big Picture: Debating China's Rebalancing. http://tinyurl.com/op9w7dr (accessed July 25, 2016).

Link, Perry. 2002. The Anaconda in the Chandelier: Censorship in China Today." New York Review of Books, April 11. http://tinyurl.com/osvmly2 (accessed July 25, 2016).

Linzer, Drew A., and Jeffrey K. Staton. 2015. A Global Measure of Judicial Independence, 19482012. Journal of Law and Courts 3 (2): 223-56.

Liu, Sida, and Terence C. Halliday. 2011. Political Liberalism and Political Embeddedness: Understanding Politics in the Work of Chinese Criminal Defense Lawyers: Politics of Chinese Criminal Defense Lawyers. Law $\mathcal{E}$ Society Review 45 (4): 831-66.

Liu, Sida, Lily Liang, and Ethan Michelson. 2014. Migration and Social Structure: The Spatial Mobility of Chinese Lawyers: Migration and Social Structure. Law E Policy 36 (2): 165-94.

Lopez, Gerald P. 1992. Rebellious Lawyering: One Chicano's Vision of Progressive Law Practice. New Perspectives on Law, Culture, and Society. Boulder, CO: Westview Press.

Lubman, Stanley. 2015. After Crackdown on Rights Lawyers, China's Legal Reform Path Uncertain. Wall Street Journal's China Realtime Blog, July 31. http://tinyurl.com/ng5stfd (accessed July 25, 2016).

Marshall, Anna-Maria, and Daniel Crocker Hale. 2014. Cause Lawyering. Annual Review of Law and Social Science 10 (1): 301-20.

Michalowski, Raymond. 1998. All or Nothing: An Inquiry into the Im(possibility) of Cause Lawyering Under Cuban Socialism. In Cause Lawyering: Political Commitments and Professional Responsibilities, ed. Stuart A. Scheingold and Austin Sarat. New York: Oxford University Press.

Michelson, Ethan. 2003. Unhooking from the State: Chinese Lawyers in Transition. PhD diss., University of Chicago, Chicago, IL.

Michelson, Ethan, and Ke Li. 2014. Judicial Performance without Independence: The Delivery of Justice and Political Legitimacy in Rural China. Draft paper on file with the author.

Michelson, Ethan, and Sida Liu. 2014. What Do Chinese Lawyers Want? Political Values and Legal Practice. In China's Emerging Middle Class: Beyond Economic Transformation, ed. Cheng $\mathrm{Li}, 310-33$. Washington, DC: Brookings Institution Press.

Ministry of Justice. 2015. Interview with the Ministry of Justice About the Opinion on Perfecting the Legal Aid System (司法部就《关于完善法律援助制度的意见》答记者问),June 30. http:// tinyurl.com/qfhrkam (accessed July 25, 2016). 
Minzner, Carl F. 2006. Xinfang: An Alternative to Formal Chinese Legal Institutions. Stanford Journal of International Law 42:103-79.

- 2015. China After the Reform Era. Journal of Democracy 26 (3): 129-43.

Mosher, Stacy, and Patrick Poon, eds. 2009. A Sword and a Shield: China's Human Rights Lawyers. Hong Kong: China Human Rights Lawyers Concern Group.

Moustafa, Tamir. 2009. The Struggle for Constitutional Power: Law, Politics, and Economic Development in Egypt. New York: Cambridge University Press.

Moustafa, Tamir. 2014. Law and Courts in Authoritarian Regimes. Annual Review of Law and Social Science 10 (1): 281-99.

Moustafa, Tamir and Tom Ginsburg. 2008. Introduction. In Rule by Law: The Politics of Courts in Authoritarian Regimes, ed. Tamir Moustafa and Tom Ginsburg, 1-22. New York: Cambridge University Press.

Munger, Frank W., Scott L. Cummings, and Louise G. Trubek. 2013-2014. Mobilizing Law for Justice in Asia: A Comparative Approach. Wisconsin International Law Journal 31:353-420.

Nathan, Andrew J. 1986. Chinese Democracy. Berkeley, CA: University of California Press.

Nonet, Philippe, and Philip Selznick. 2001. Law $\mathcal{E}$ Society in Transition: Toward Responsive Law. New Brunswick, NJ: Transaction Publishers.

Ocko, Jonathan K. 1988. I'll Take It All the Way to Beijing: Capital Appeals in the Qing. Journal of Asian Studies 47 (2): 291-315.

Osnos, Evan. 2014. Age of Ambition: Chasing Fortune, Truth, and Faith in the New China, 1st ed. New York: Farrar, Straus and Giroux.

Pereira, Anthony W. 2005. Political (In)justice: Authoritarianism and the Rule of Law in Brazil, Chile, and Argentina. Pitt Latin American Series. Pittsburgh, PA: University of Pittsburgh Press.

Pils, Eva. 2006-2007. Asking the Tiger for His Skin: Rights Activism in China. Fordham International Law Journal 30:1209-87.

. 2014. China's Human Rights Lawyers: Advocacy and Resistance. Routledge Research in Human Rights Law. Milton Park, Abingdon, Oxon/New York: Routledge.

Potter, Pitman. 2011. 4 June and Charter 08: Approaches to Remonstrance. China Information 25 (2):121-38.

Rajah, Jothie. 2011. Punishing Bodies, Securing the Nation: How Rule of Law Can Legitimate the Urbane Authoritarian State. Law $\mathcal{E}$ Social Inquiry 36 (4): 945-70.

Sarat, Austin, and Stuart A. Scheingold, eds. 2001. Cause Lawyering and the State in a Global Era. Oxford Socio-Legal Studies. Oxford/New York: Oxford University Press.

- eds. 2006. Cause Lawyers and Social Movements. Stanford, CA: Stanford Law and Politics.

Schell, Orville, and John Delury. 2013. Wealth and Power: China's Long March to the Twenty-First Century. New York: Random House.

Scott, James C. 1987. Weapons of the Weak: Everyday Forms of Peasant Resistance. New Haven, CT: Yale University Press.

Shamir Ronen, and Sara Chinski. 1988. Destruction of Houses and Construction of a Cause: Lawyers and Bedouins in the Israeli Courts. In Cause Lawyering: Political Commitments and Professional Responsibilities, ed. Austin Sarat and Stuart Scheingold, 227-57. New York: Oxford University Press.

Silverstein, Gordon. 2003. Globalization and the Rule of Law: A Machine that Runs of Itself? International Journal of Constitutional Law 1 (3): 427-45.

Stern, Rachel E. 2013. Environmental Litigation in China: A Study in Political Ambivalence. New York: Cambridge University Press.

Stern, Rachel E., and Jonathan H. Hassid. 2012. Amplifying Silence: Uncertainty and Control Parables in Contemporary China. Comparative Political Studies 45 (10): 1230-54.

Stern, Rachel E, and Kevin J. O'Brien. 2012. Politics at the Boundary: Mixed Signals and the Chinese State. Modern China 38 (2): 174-98.

Supreme People's Court (SPC). 2015. Report from SPC Spokesperson on the Current Situation Regarding the Case Filing Registration System" [Zui Gaorenmin Fayuan Fayanren Tongbao Quanguo Fayuan Shishi Li'an Dengi Zhidu Jinzhan Qingkuang]. SPC press release, June 9. http://tinyurl.com/nggq8k4 (accessed July 25, 2016). 


\section{LAW \& SOCIAL INQUIRY}

Vanhala, Lisa. 2010. Making Rights a Reality?: Disability Rights Activists and Legal Mobilization. Cambridge Disability Law and Policy Series. Cambridge/New York: Cambridge University Press.

2012. Legal Opportunity Structures and the Paradox of Legal Mobilization by the Environmental Movement in the UK: The Paradox of Legal Mobilization by the UK Environmental Movement. Law $\mathcal{G}$ Society Review 46 (3): 523-56.

Wang, Yuhua. 2015. Tying the Autocrat's Hands: The Rise of the Rule of Law in China. New York: Cambridge University Press.

Wei, Rujiu. 2015. Concerns About Weiquan Lawyers [中国维权律师的有思虑,” January 18. http:// tinyurl.com/o7njs2q (accessed July 25, 2016).

Xinhua News Agency. 2014. Highlights of Work Report of China's Supreme People's Court. March 10. http://tinyurl.com/pz8pq2y (accessed July 25, 2016).

2015. China Champions Legal Protection of Human Rights, July 24. http:/tinyurl.com/ qh42juv (accessed July 25, 2016).

Xu, Weiping. 2015. How to Correctly Understand the Case Filing Registration System [Zenyang zhengque lijie li'an dengiizhi], June 1. People's Court Daily [Renmin Fayuan Bao]. http://tinyurl. com/nv4fmtl (accessed July 25, 2016).

Yap, Po Jen, and Holning Lau, eds. 2010. Public Interest Litigation in Asia. London/New York: Routledge. 